\title{
A CASE STUDY OF PRE-SERVICE CRACKS IN THE CONCRETE DECKS OF A TWO-LEVEL BASEMENT CAR PARK
}

\author{
P.G. KOSSAKOWSKI ${ }^{1}$, J. ŚLUSARCZYK ${ }^{2}$
}

\begin{abstract}
This paper deals with the prevention of failure of structural elements made of reinforced concrete. It discusses preservice cracks in the concrete decks of an underground parking facility. The cracks were assessed by analyzing their morphology. The results were used to determine the crack causes and the mechanisms of their initiation and growth. Some design solutions to prevent or reduce the occurrence of pre-service cracks are also presented.
\end{abstract}

Keywords: concrete, failure prevention, crack, basement car park.

\section{INTRODUCTION}

It is standard practice that a building erected in an urban area, where the cost of land is very high, has underground floors, for instance, to offer sufficient parking facilities [1]. A frequent solution is to make the substructure larger than the superstructure. In many a case, basement walls extend close to the property boundaries. This requires using a special building technology, for example, a closed system of slurry walls. The basement can be constructed without 'entering' the neighbouring parcels of land using

\footnotetext{
${ }^{1}$ DSc., PhD., Eng., Kielce University of Technology, Faculty of Civil Engineering and Architecture, Al. Tysiąclecia Państwa Polskiego 7, 25-314 Kielce, Poland, e-mail: kossak@tu.kielce.pl

${ }^{2}$ PhD., Eng., Kielce University of Technology, Faculty of Civil Engineering and Architecture, Al. Tysiąclecia Państwa Polskiego 7, 25-314 Kielce, Poland, e-mail: jaceks@tu.kielce.pl
} 
a method in which thedeck is also responsible for pressing against the slurry walls to keep them in place both during the construction and operation of the building.

Projects of this type require high-quality design and construction. Their complexity implies that various types of flaws may occur [2]. This paper describes one of such flaws, i.e., undesirable cracks in the decks of underground parking facilities, discovered on completion just before the building was open. The investigations involved assessing the cracks by analysing their morphology and determining their cause. The paper also mentions some solutions designed to reduce or prevent the occurrence of this type of cracks and the role of the so-called minimum cross-sectional area of reinforcement [3-4].

\section{STRUCTURE OF THE SLAB DECKS FOR THE UNDERGROUND PARKING FACILITIES}

The structure under study is a two-level basement (Fig. 1) extending beyond the superstructure walls, which is used for parking. Both slab decks were designed as non-beam decks with a thickness of $30 \mathrm{~cm}$. They were constructed using C30/37 concrete and class A steel (grade RB 500W).

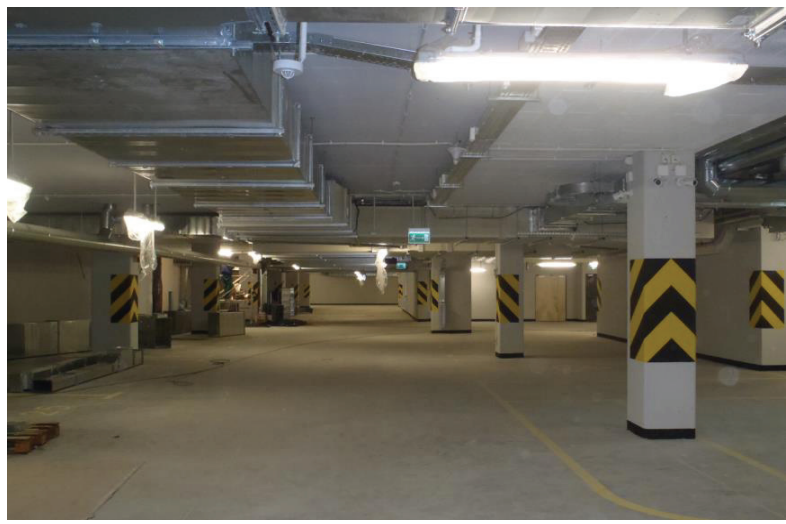

Fig. 1. View of level -1

The deck viewed from level -1 is thicker between axes $A$ and $C$; this is where the fire escape route runs. The floor finish and the structure of the deck depends on the function. The deck viewed from level -1 
consists of the following layers: industrial flooring, sloped mortar bed $(5-10 \mathrm{~cm})$ and a $30 \mathrm{~cm}$ thick reinforced concrete slab. However, the layers of the deck where the fire escape route runs are, from the top downwards, pavers, sand setting bed, geotextile membrane, fine and coarse aggregate, a drainage layer, waterproofing membrane, extruded polystyrene rigid insulation and a $35 \mathrm{~cm}$ thick reinforced concrete slab. The deck viewed from level -2 consists of the following layers: industrial flooring, sloped mortar bed $(5-10 \mathrm{~cm})$ and a $30 \mathrm{~cm}$ thick reinforced concrete slab.

An orthogonal grid of pillars with a maximum size of $8.10 \times 8.15 \mathrm{~m}$ was used. The deck slabs are supported by the walls of two centrally located service ducts and the exterior slurry walls around the perimeter of the basement. The decks, generally with rigid peripheral ties, were constructed using no expansion joints, although the length of the building is nearly $70 \mathrm{~m}$. It was a challenging solution even though concrete placing was performed in stages. The rebars 12 and $16 \mathrm{~mm}$ in diameter spaced 10 and $20 \mathrm{~cm}$ apart were used for the primary reinforcement of the concrete slabs. The static calculations involved analysing the flexural behaviour of the slabs pushing against the slurry walls under preoperation and operation conditions. Forces due to concrete shrinkage or changes in the air temperature were not taken into account. The rebars of the top and bottom reinforcement varied in diameter across the entire area of the deck. The ratio of the total area of the top and bottom reinforcement to the total cross-sectional area of the slabs ranged from 0.4 to $0.7 \%$. The basement including the deck on level -1 is made of concrete W8. The basement not only has a structural function, it also serves as insulation, with the slurry walls forming the so-called water-tight bathtub.

Before the building was ready for operation, undesirable cracks occurred on the underside of the deck viewed from level -1 . In some areas, there were water drops on the surface indicating that the horizontal barrier was not leak tight. This required performing a detailed inspection of the deck surface (the deck underside) on both levels and producing a comprehensive report.

\section{MORPHOLOGY OF THE PRE-SERVICE CRACKS}

In the deckviewed from level-2, cracks were found in the peripheral ties, i.e., those adjacent to the slurry walls. The cracks are illustrated in Fig. 2 (crack width measurement sites Nos. 6 - 12). 


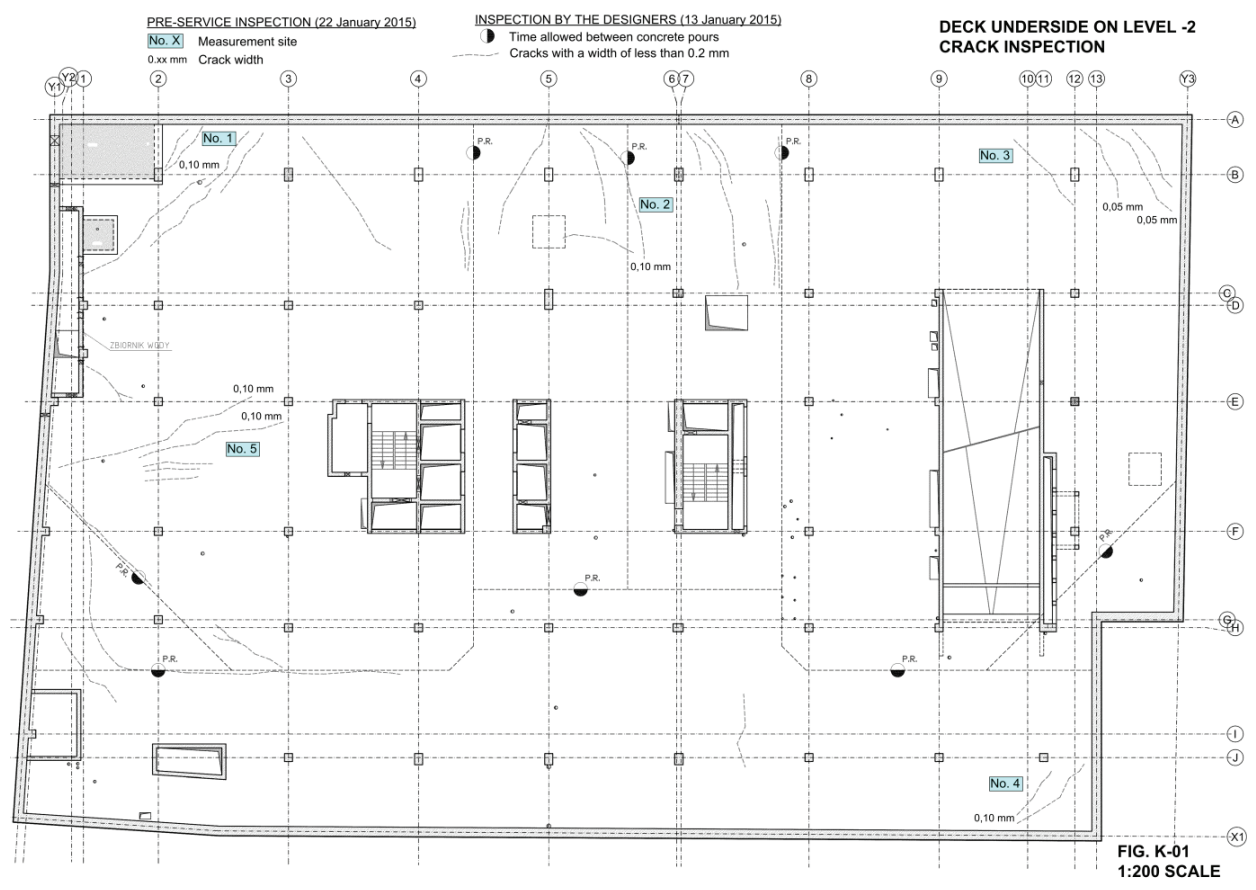

Fig. 2. Illustration of the cracks in the deck viewed from level -2 (pre-service inspection report)

A particularly large number of cracks were found in the ties along the longer sides of the undergrounddecks. The direction of the cracks in the deck was almost always perpendicular to the slurry wall line except for those in the corner. Practically all the cracks began in the area where the deck met the slurry wall (Fig. 3a). 


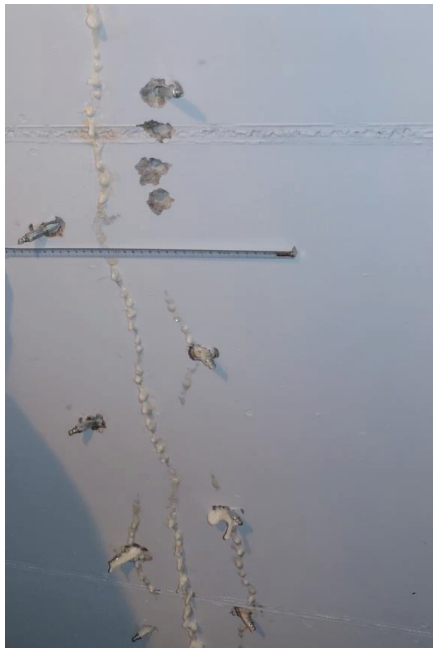

a)

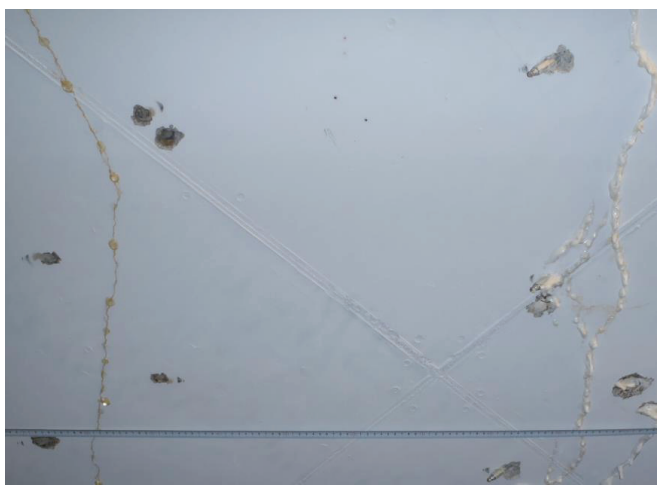

b)

Fig. 3. a) Site 7: cracks in the deck viewed from level -1; b) Site 10: cracks in the deck viewed from level -1

The crack growth direction is slightly different only in the deck area adjacent to two mutually perpendicular slurry wall sections. The deck area adjacent to the perpendicular (corner) slurry wall sections have cracks nearly perpendicular to the angle bisector formed by two adjacent slurry wall sections. Thus the corner deck area at the slurry wall corner contains cracks inclined at about $45^{\circ}$ to the parting line between two adjacent slurry wall sections (Fig. 2).

Cracks were not present in all the peripheral tiesof thedeck and their distribution differed between the areas designated within them. The distances between the cracks were of an order of $0.5 \mathrm{~m}$. Cracks with a width of more than $0.2 \mathrm{~mm}$ were not found. The width of the cracks ranged between $0.05 \mathrm{~mm}$ and 0.10 $\mathrm{mm}$. The seepage of rainwater indicated that the cracks extended across the entire thickness.

In the areas where cracks occurred, no deviation from flatness of the surfaceof the deck underside was observed.

The cracks in the deckviewed from level -2 reported at crack width measurement sites \#1-5 practically did not differ in location, growth direction, growth intensity or width from the cracks found in the deckviewedfrom level -1 (Fig. 4). 


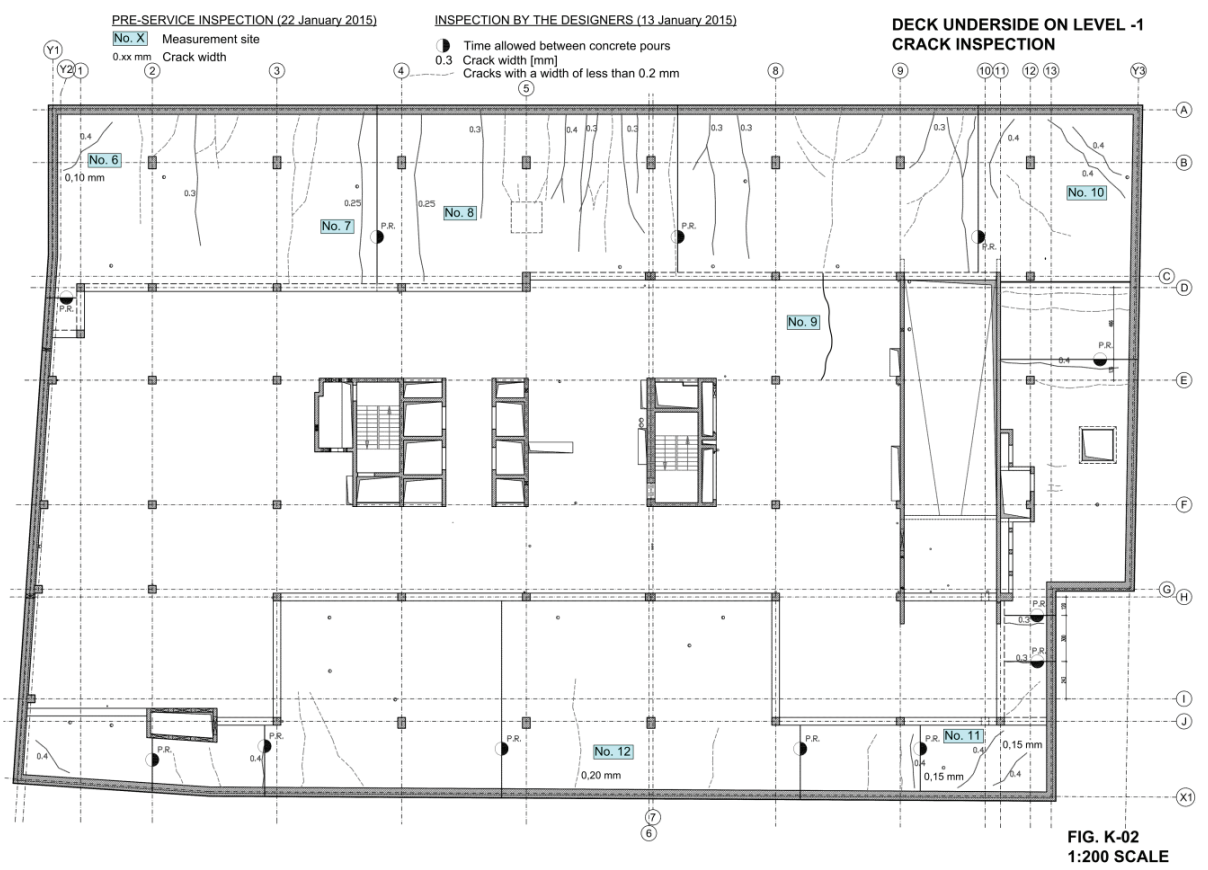

Fig. 4. Illustration of the cracks in the deck viewed from level-1 (pre-service inspection report)

Cracks were observed in the peripheral ties, i.e., ones adjacent to the slurry wall. The crack growth direction in the deck slab was also almost perpendicular to the slurry wall line. Like for level -1 , the cracks generally had one end located in the area where the deck slab was in contact with the slurry wall (Fig. 5).

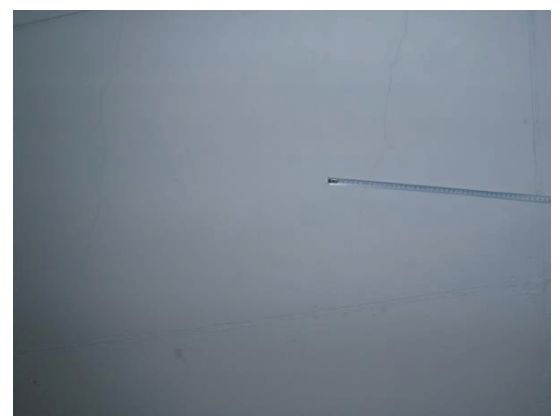

Fig. 5. Site 2: cracks in the deck underside viewed from level -2 
Also in the deck areas adjacent to two mutually perpendicular slurry wall sections, the cracks were almost perpendicular to the angle bisector formed by the parting line between the slurry wall sections.

The inspection did not confirm that the cracks propagated across the whole thickness of the slab because it was an interfloor slab and no access was available to the top because of the flooring.

\section{CRACK WIDTH CONTROL BY USING MINIMUM REINFORCEMENT IN ACCORDANCE WITH EUROCODE 2}

In reinforced concrete buildings with cast-in-place structural elements, deformations may occur due to fixed external restraints. Some basic examples are shown in Fig. 6.
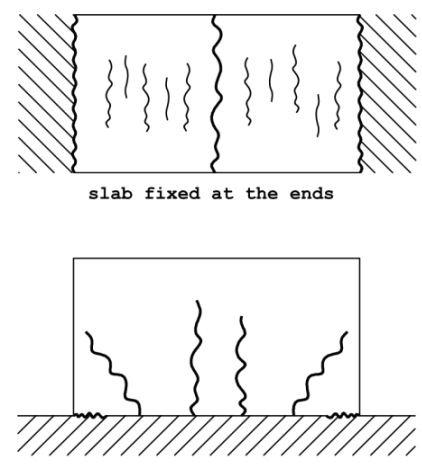

slab fixed along the bottom

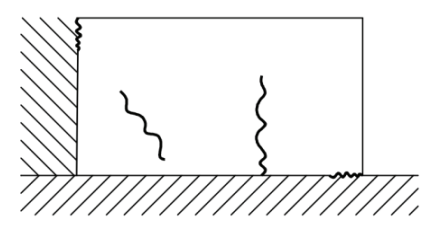

slab fixed along the bottom and one side

Fig. 6. Deformations imposed by fixed external restraints

The phenomena that may be responsible for the occurrence of this type of deformations include:

- concrete shrinkage,

- a fall in temperature. 
However, the factors affecting the cracking differ in the two cases. In practice, forced deformations are observed after:

- placing concrete in between two existing sections,

- placing concrete to extend the existing section on either of the restrained edges.

The stresses that occur are dependent, for instance, on the translation restraint factor. It is possible to minimize the stresses and their effects by applying appropriate procedures. The simplest method to control the width of cracks caused by forced deformations is to use minimum reinforcement (Eurocode 2). Considering the bonding between steel and concrete, we can calculate the required diameter of the reinforcement bar from the conditions of equilibrium between the tensile force in the concrete before cracking and the tensile force in the concrete after cracking. The minimum reinforcement can be calculated using the following formula:

$$
\mathrm{A}_{\mathrm{s}, \min }=\mathrm{k}_{\mathrm{c}} \mathrm{kf}_{\mathrm{ct}, \mathrm{eff}} \mathrm{A}_{\mathrm{ct}} / \sigma_{\mathrm{s}}
$$

The minimum reinforcement is expected to resist the forces responsible for the cracking of the whole deck by reducing stress in the steel, which means a relatively small elongation of the steel bars in the crack area. $\sigma_{\mathrm{s}}$ is the absolute value of the maximum stress permitted in the reinforcement immediately after the formation of the crack. The acceptable maximum stress in the reinforcement is the characteristic reinforcement yield stress, $f_{\mathrm{yk}}$. Limiting crack widths requires assuming a lower value of the acceptable stress dependent on the bar diameter and the bar spacing. The whole tensile force is restrained by the reinforcement.

Factor $\mathrm{k}$ takes into account the influence of non-uniform, self-balancing stresses, which lead to a reduction in the forces generated by forced deformations. Factor $\mathrm{k}$ can be used to reduce the tensile strength of concrete; the effect of self-stressing material reducing the element resistance to cracking was taken into consideration in the respective formulae. Factor $\mathrm{k}_{\mathrm{c}}$ allows for the nature of the stress distribution within the section immediately prior to cracking and for the change of lever arm as a result of cracking. For pure tension $\mathrm{k}_{\mathrm{c}}=1.0$.

$\mathrm{f}_{\mathrm{ct}, \text { eff }}$ is the mean value of the tensile strength of concrete, effective at the time cracks may be first expected to occur. $A_{c t}$ is the area of concrete in that part of the section which is calculated to be in tension just before the formation of the first crack. 


\section{CRACK ASSESSMENT AND REPAIR}

The investigations showed that the cracks were relatively regular in shape and their orientation was defined in relation to the slurry walls. Cracks occurred in the peripheral ties of the decks.

In this study it was assumed that internal forces caused by gravity loading were not responsible for the cracking. It should be noted that the location and layout of cracks in the deck under excessive gravity loading are completely different. Examples of calculation results are shown in Figs. 7 and 8.

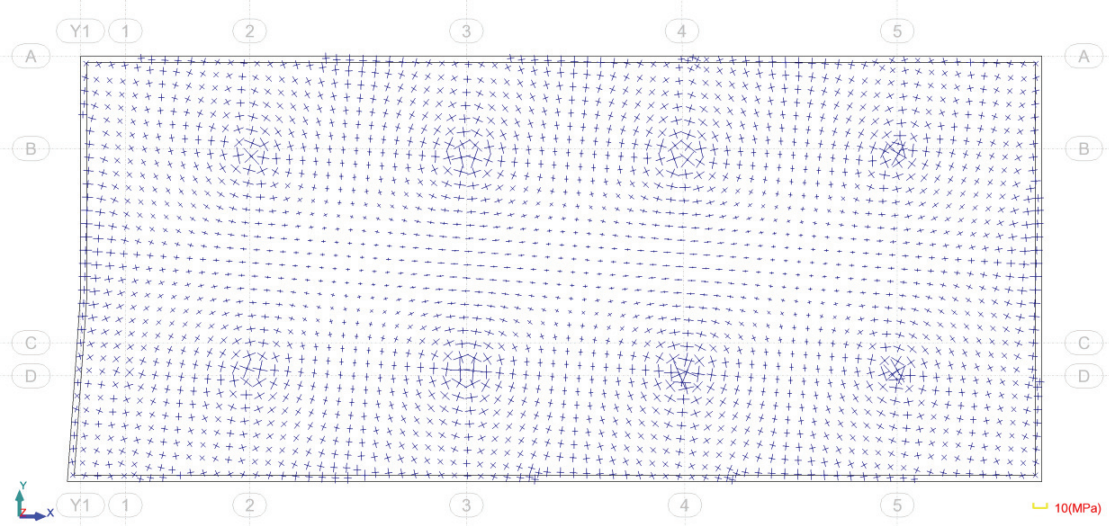

Fig. 7. Directions of the primary stress

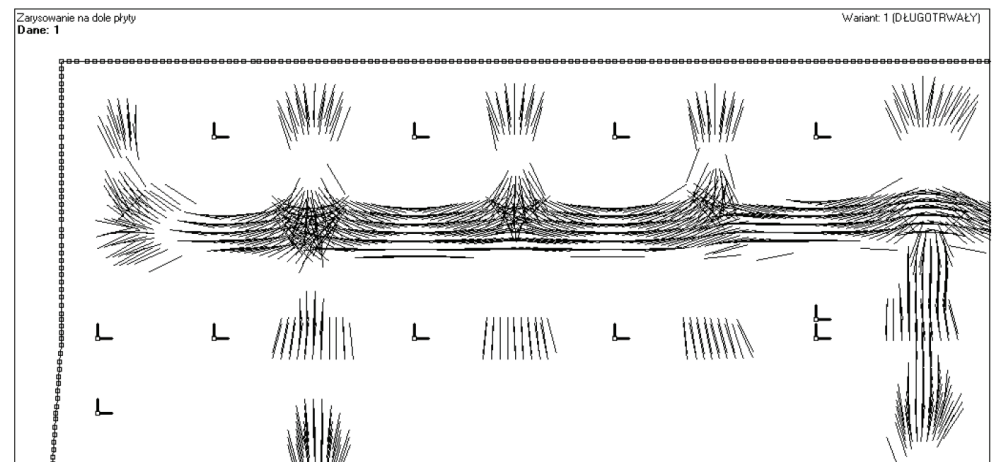

Fig. 8. Map of cracking on the slab underside [5] 
Because of the minimum cross-sectional area of reinforcement (minimum bar diameter and minimum bar spacing) the crack width was small and the cracks were spaced relatively evenly. As the cracks had negligible influence on the deck behavior under gravity loading, they were repaired using elastic polyurethane resin.

The flatness of the underside of the decks was assessed by measuring the distance to the floor with a laser tape measure and a leveling instrument. The vertically measured ordinates allowed us to draw a map of cracks present on the underside of the decks viewed from levels -2 and -1 . The measurement profiles in selected areas were almost linear in nature.

The flatness of the decks was also measured using a three-meter rod. In many different positions, the ends of the rod always touched the underside of the decks. This suggests that the surface of the underside of the decks viewed from levels -2 and -1 was flat.

As the deck in the crack area was flat with no curvatures or deformations it can be claimed that the state of cracks was not a result of the bending moments. The cracks in the deck were not caused by the action of a one-sided, vertical gravity loading, nor were they the effect of the temperature gradient across the deck thickness.

The seepage through the cracks in the deck on level -1 indicated that the cracks had split and propagated across the entire thickness of the slab. This suggests that the cracking was due to tensile stresses distributed across the whole thickness of the slab (from the bottom to the top). Thus, the initiation and growth of cracks occurred according to the Rankine criterion based on the condition that normal stresses exceeded the tensile strength of the concrete used for the decks. Normal stresses occurred as a result of concrete shrinkage [6] or a drop in the outside temperature.

The crack growth directions clearly suggest that the deformations were restrained by the existing peripheral ties. The cracks represented the linear resistance of thedeck. The response of the slabs to such processes as concrete setting, hardening and shrinkage was their natural deformation. These deformations were restrained by the rigid-in-its-plane slurry wall that the deck slabs were joined with. The cracks propagated perpendicular to the line of the slurry wall, which resisted the natural deformations caused by the shrinkage of concrete in the deck slabs or a drop in their temperature. The rigidity of the ties was high and the reason for that was not only the adherence of concrete to concrete placed at different times. The deck reinforcement was anchored into the vertical reinforcement of the slurry wall. Placing concrete at time intervals reduced or completely eliminated the effects of shrinkage. The peripheral ties were thus responsible for the generation of tensile stresses distributed 
along the whole thickness of the deck slab. The restraint of the deformations is best visible in the corner areas. The ties occurring along two mutually perpendicular walls led to the formation of diagonal cracks, practically perpendicular to the bisector of the angle formed by the parting line between the slurry wall sections.

The slabs were produced by placing concrete at time intervals not only to prevent concrete shrinkage but also because of the technology used to construct the underground floors. As can be seen, the stresses generated during concrete placing were so high that relaxation of tensile stresses was essential. The greatest deformations attributable to concrete shrinkage had actually occurred before the inspection; almost no increase was reported during the examinations. Some of the unavoidable forced stresses are those caused by the resistance of the reinforcement to prevent natural shrinkage of concrete. In this case, however, it was not of key importance.

The state of stresses resulting from the occurrence of tensile stresses could be improved by simultaneously reducing the temperature of the deck and the temperature of air. Because of the low mass of the slabs, the temperature gradients related to the cement hydration heat only [7-8] were quite small. It was found that the maturing concrete did not generate considerable residual stresses.

It was assumed that no significant tensile forces would occur in the deck slabs under service conditions. Another assumption was that the forces due to concrete shrinkage had decreased sufficiently. It was thus concluded that the process of split cracking was practically over and the cracks were stable. An ND type Schmidt hammer was used to determine the strength of the concrete. The non-destructive testing inspection was performed according to the relevant standard and the manual by the Institute of Construction Engineering. The concrete strength was determined from the rebound readings obtained for six randomly selected points. On the inspection day, the characteristic cylinder strength of the concrete slab $\left(\mathrm{f}_{\mathrm{ck}}\right)$ viewed from level -2 was approximately $60 \mathrm{MPa}$, while that viewed from level -1 was about $50 \mathrm{MPa}$. Examples of the measurement results are provided in Fig. 9. 

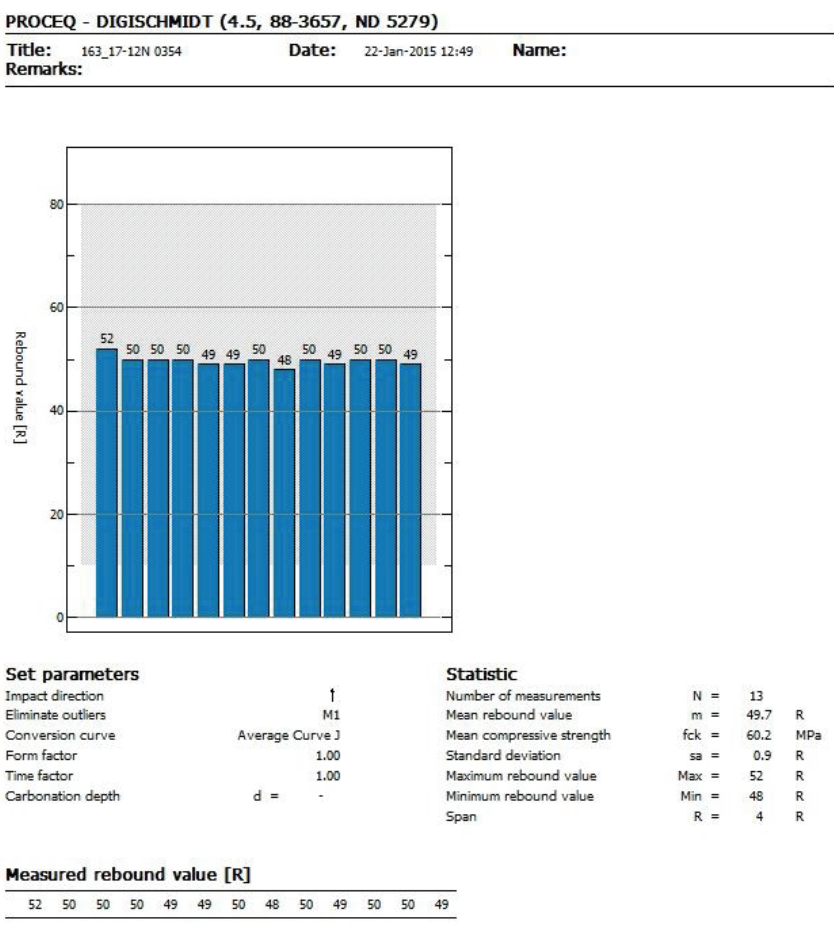

Fig. 9. Results of the Schmidt hammer tests for one of the measurement points

The non-destructive tests showed that the designed strength class of concrete had already been achieved. Standard calculations confirmed that the building was safe to use and the load-carrying capacity of the decks would be sufficient under service conditions. The effect of a considerable drop in the deck temperature was not analysed.

The structure of the deck and the minimum cross-sectional area of reinforcement contributed to the relatively uniform distribution of cracks caused by forced deformations and their limited width. If the width of a crack does not exceed $0.2 \mathrm{~mm}$, the crack is actually acceptable by standard for the XD1 exposure class. It was assumed that the seepage would probably stop with time because of the formation of self-sealing $\mathrm{CaCO}$. The deckviewed from level -1 required immediate sealing by injection (Fig. 10), which is a standard procedure. 


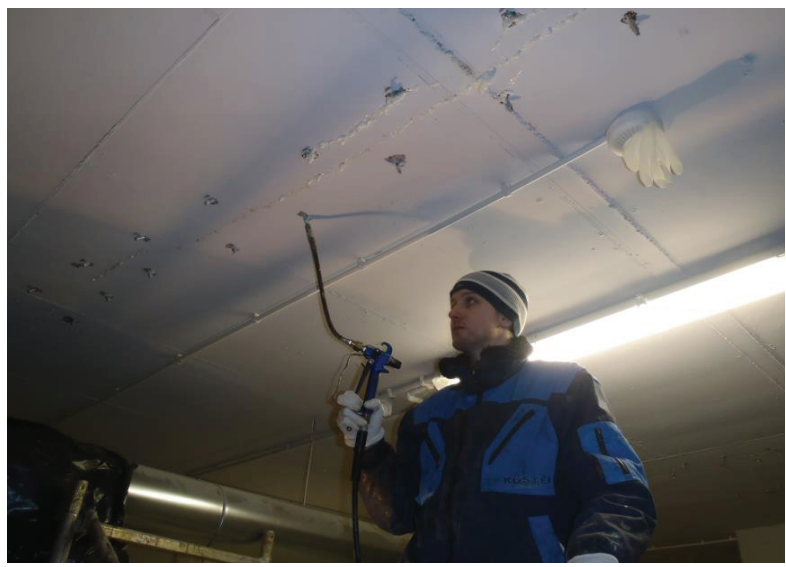

Fig. 10. Crack sealing at site 8

Elastic polyurethane resin was used for this purpose. It was also recommended that the behaviour of both decks be monitored in the initial period of operation of the building in order to empirically confirm the stability of the existing cracks.

\section{CONVENTIONAL METHODS TO LIMIT THE INFLUENCE OF FORCED DEFORMATIONS}

Cracking is considered an inherent feature of reinforced concrete. This does not imply, however, that the phenomena cannot be controlled at the construction or operation stages. In the case of a non-massive element, like the one described here, the strength of concrete can be exceeded as a result of the occurrence of forced stresses. There are a couple of causes of these stresses. One is free deformation of an element attributable to such processes as concrete setting, hardening or shrinkage. The other is resistance to this deformation generated by the peripheral and internal (reinforcement induced) ties. Minimising stresses of this type requires taking account of:

- the size and location of the plots,

- the length of joints between new and existing concrete (the latter with shrinkage deformations present),

- the necessity to use cement with special properties,

- the necessity to perform special maintenance operations, 
- the temperature of concrete as placed.

Currently, the use of a variety of modern computer programs and methods, usually based on the finite element method (FEM) is applied in the design and research on the concrete structures [e.g., 9]. Today's software tools for FEM analysis $[10,11]$ make it possible to assess the likelihood of the occurrence of cracks in a concrete structure before its operation, similarly to the effects of failure observed in other structural materials [e.g., 12, 13]. If cracks are assumed to appear, the general approach is to control only their width. The initiation of the damage processes of concrete structural elements take place in the material structure and several models and theories describing these processes are determined [14-18] similarly as for other materials [19-21]. They mey represent the first step in analyzing the behavior of the concrete under different conditions $[22,23]$.

In simple cases, the width of cracks due to forced deformations is controlled by determining the so-called minimum cross-sectional area of reinforcement [3], [4]. This involves assessing the force acting on the steel reinforcement and its response. The stresses that occur cannot cause the steel to flow and their values must correspond to the acceptable crack width. For example, if we control cracks that are due to external factors and they extend across the whole thickness of a slab, the force acting on the reinforcement is determined directly as a ratio of $\mathrm{A}_{\text {ct }}$ to $\mathrm{f}_{\mathrm{ct} \text {,eff. }}$. One factor is the cross-sectional area of the concrete element and the other is the estimated tensile strength of the concrete before a crack occurs. Reinforcement of this type is particularly vital for elements where external loads do not lead to considerable internal forces.

\section{CONCLUSIONS}

The analysis of the deck cracks in this example indicates that forced interactions can be of significance not only with regard to massive structures. Minimisation of ties accompanying deformations resulting from the shrinkage of concrete or a decrease in the outside temperature is particularly crucial when the concrete is also to act as a leak tight barrier. In such a case, special solutions are required at all the stages, from design to construction, including appropriate concrete technology and construction technology.

Slurry walls, which constitute the external restraints for the decks, provide significant resistance to their thermal and shrinkage deformations. The influence of thermal stresses is actually similar to that of shrinkage stresses. Shrinkage deformations are always negative. Thermal deformations, however, are negative only at a drop in the outside temperature. Even though the two types of stresses did not occur 
simultaneously and their signs differed, they were sufficient to cause considerable forces to occur in the contact zones between the decks and the slurry wall. The resulting tension led to the occurrence of cracks propagating across the entire thickness of the slabs.

The cracking did not affect the load-carrying capacity of the structure but the stiffness of the decks was slightly reduced. The major undesirable effect is the loss of water tightness, which under unfavorable weather conditions may allow rainwater to seep through the concrete. This problem refers mainly to the deck viewed from level -2, whose functions are both load-carrying and insulation (water-tight bathtub). 


\section{REFERENCES}

1. H. Michalak, "Spatial and structural planning of underground garages on highly industrialized areas", Warsaw Technical University Publishing, Architecture - 2, Warsaw 2006, (in Polish).

2. J. Ślusarczyk, "Identification and assessment of defects in a multi-storey car park”, Przegląd Budowlany No. 1/2011, 34-39, (in Polish).

3. PN-EN 1992-1-1:2008 Eurocode 2 - Design of concrete structures - Part 1-1: General rules and rules for buildings".

4. CEB-FIP fib. Model Code 2010, 2013.

5. J. Figura, R. Gralak, A commercial building with a basement car park. Inspection report on the causes of crack occurrence in structural elements of the basement levels (in Polish), Warszawa 2015.

6. K. Flaga,"The influence of concrete shrinkage on durability of reinforced structural members", Bulletin of the PolishAcademy of Sciences. Technical Sciences 63: 15-22, 2015.

7. B. Klemczak,A. Knoppik-Wróbel,“Analysis of early-age thermal and shrinkage stresses in reinforced concrete walls, ACI Structural Journal 111:313-322, 2014.

8. F.S. Rostàsy, M. Krauß, "Frühe Risse in massigen Betonbauteilen - Ingenieurmodelle für die Planung von Gegenmaßnahmen”, DAfStb Heft 512, Beuth Verlag GmbH, Berlin, 2001, (in Deutsch).

9. M. Szczecina, A. Winnicki, "Selected Aspects of Computer Modeling of Reinforced Concrete Structures", Archives of Civil Engineering 62: 51-64, 2016.

10. B. Klemczak, "Modeling thermal-shrinkage stresses in early age massive concrete structures - Comparative study of basic models", Archives of Civil and Mechanical Engineering 14: 721-733, 2014.

11. Solver Reference Manual, Version 14.7, Lusas, Kingston upon Thames, 2011.

12. P. G. Kossakowski, "Stress Modified Critical Strain criterion for S235JR steel at low initial stress triaxiality”, Journal of Theoretical and Applied Mechanics 52: 995-1006, 2014.

13. P. G. Kossakowski, "Microstructural failure criteria for S235JR steel subjected to spatial stress states", Archives of Civil and Mechanical Engineering 15: 195-205, 2015.

14. J.Mazars, "A description of micro- and macroscale damage of concrete structures", Engineering Fracture Mechanics 25: 729-737, 1986.

15. E. N. Landis, "Micro-macro fracture relationships and acoustic emissions in concrete", Construction and Building Materials 13: 65-72, 1999.

16. J. O. Faria, M. Cervera, "A strain-based plastic viscous-damage model for massive concrete structures", International Journal of Solids and Structures 35: 1533-1558,1998.

17. S. Yazdani, H. Schreyer, "Combined Plasticity and Damage Mechanics Model for Plain Concrete", Journal of Engineering Mechanics 116: 1435-1450, 1990.

18. Z. P.Bazant,"Nonlocal damage theory based on micromechanics of crackinteraction”, Journal of Engineering Mechanics ASCE 120: 593-617, 1994.

19. P. G. Kossakowski, W. Wciślik, Experimental determination and application of critical void volume fraction $\mathrm{f}_{\mathrm{c}}$ for S235JR steel subjected to multi-axial stress state, in: T. Łodygowski, J. Rakowski, P. Litewka (Eds.), Recent Advances in Computational Mechanics, CRC Press/Balkema, London, 2014, pp. 303-309.

20. P. G. Kossakowski, W. Wciślik, "Effect of critical void volume fraction $\mathrm{f}_{\mathrm{F}}$ on results of ductile fracture simulation for S235JR steel under multi-axial stress states", Key Engineering Materials - Fracture and Fatigue of Materials and Structures 598: 113-118, 2014.

21. J. L.Chaboche, P. M. Lesne, J. F. Maire, "Continuum Damage Mechanics, Anisotropy and Damage Deactivation for Brittle Materials Like Concrete and Ceramic Composites”, International Journal of Damage Mechanics 4: 5-22, 1995.

22. B. Vakhshouri, S. Nejadi, "Prediction Of Compressive Strength In Light-Weight Self-Compacting Concrete By ANFIS Analytical Model”, Archives of Civil Engineering 61: 53-72, 2015.

23. L. X. Xiong, "Uniaxial Dynamic Mechanical Properties Of Tunnel Lining Concrete Under Moderate-Low Strain Rate After High Temperature", Archives of Civil Engineering 61: 35-52, 2015. 


\section{LIST OF FIGURES:}

Fig. 1. View of level -1

Rys. 1. Widok kondygnacji poziomu -1

Fig. 2. Illustration of the cracks in the deck viewed from level -2 (pre-service inspection report)

Rys. 2. Inwentaryzacja zarysowań stropu widocznych z poziomu -2 (ekspertyza techniczna)

Fig. 3. a) Site 7: cracks in the deck viewed from level-1; b) Site 10: cracks in the deck viewed from level -1

Rys. 3. a) Stanowisko7: zarysowania stropu widoczne z poziomu -1; b) Stanowisko10: zarysowania stropu widoczne z poziomu -1 ;

Fig. 4. Illustration of the cracks in the deck viewed from level -1 (pre-service inspection report)

Rys. 4. Inwentaryzacja zarysowań stropu widocznych z poziomu -1 (ekspertyza techniczna)

Fig. 5. Site 2: cracks in the deck underside viewed from level -2

Rys. 5. Stanowisko 2: zarysowania spodu stropu widoczne z poziomu -2

Fig. 6. Deformations imposed by fixed external restraints

Rys. 6. Odkształcenia wymuszone są przez sztywne opory zewnętrzne

Fig. 7. Directions of the primary stress

Rys. 7. Kierunki naprężeń głównych

Fig. 8. Map of cracking on the slab underside [5]

Rys. 8. Mapy zarysowania spodu płyty [5]

Fig. 9. Results of the Schmidt hammer tests for one of the measurement points

Rys. 9. Wyniki badań sklerometrycznych dla jednego z punktów pomiarowych

Fig. 10. Crack sealing at site 8

Rys. 10. Iniekcja rys w obrębie stanowiska 8 


\section{STUDIUM PRZYPADKU ZARYSOWANIA DWUPOZIOMOWEGO PARKINGU PODZIEMNEGO}

Keywords: betom, zapobieganie uszkodzeniu, rysa, garaż podziemny

\section{SUMMARY}

Przy realizacji budynku na drogim gruncie standardem jest wykonywanie kondygnacji podziemnych. Są one niezbędne chociażby ze względu na zapewnienie odpowiedniej liczby miejsc parkingowych. Niejednokrotnie zdarza się, że poziomy podziemne dochodzą do granic działki. Wymaga to zastosowania odpowiedniej technologii realizacji. Najczęściej w tym celu jest wykorzystywany zamknięty układ ścian szczelinowych.

Przedsięwzięcia tego typu wymagają zarówno dobrych projektów jak i starannego wykonawstwa. Ich złożoność sprzyja powstawaniu różnego typu usterek. W artykule na stosownym przykładzie opisano jedną z możliwych. Dotyczy ona niepożądanego zarysowania podziemnych stropów parkingu ujawnionego tuż przed rozpoczęciem eksploatacji.

Podziemny parking budynku został zlokalizowany na dwóch kondygnacjach podziemnych wychodzących poza obrys budynku. Płyty stropowe nad poziomem -2 i -1 zostały zaprojektowane zasadniczo jako bezbelkowe o grubości $30 \mathrm{~cm}$. Do ich wykonania użyto betonu klasy C30/37 i stali klasy A gatunku RB 500W. Siatka słupów ortogonalna o maksymalnym wymiarze $8,10 \times 8,15 \mathrm{~m}$. Do podparcia płyt stropowych wykorzystano ściany dwóch centralnych trzonów komunikacyjnych i obwodowe ściany szczelinowe. W stropach z zasady o niepodatnych więzach obwodowych zastosowano rozwiązanie bezdylatacyjne, gdzie większy wymiar ma blisko $70 \mathrm{~m}$. Jest to dość śmiałe rozwiązanie nawet przy zakładanym projektem etapowaniu betonowania. Wbudowane zbrojenie główne stanowią pręty \# 12 i \# 16 o odpowiednio regulowanych rozstawach 10 i $20 \mathrm{~cm}$. Na całej powierzchni stropu zastosowano zmienny stopień zbrojenia. Łączna powierzchnia zbrojenia górnego i dolnego do całkowitego przekroju płyty wynosi od 0,4 do $0,7 \%$. Konstrukcja części podziemnej wraz ze stropem nad poziomem -1 wykonana $\mathrm{z}$ betonu W8 oprócz zasadniczych zadań konstrukcyjnych ma do spełnienia również funkcję izolacyjną. Stanowi tzw. „białą wannę".

Tuż przed oddaniem obiektu do eksploatacji, na spodzie stropu nad poziomem -1 w niektórych miejscach pojawiły się krople wody sygnalizujące brak szczelności przegrody poziomej. Stało się to sygnałem do przeprowadzenia szczegółowych oględzin spodu stropów nad poziomem -2 i -1 .

Zarysowania płyty stropowej nad poziomem -1 dotyczą pasm zewnętrznych a więc przylegających do ściany szczelinowej. Szczególnie duża liczba rys występuje w paśmie od strony, przebiegającym wzdłuż najdłuższego boku kondygnacji podziemnych. Kierunek zarysowań płyty stropowej jest właściwie zawsze prostopadły do linii przebiegu ściany szczelinowej. Praktycznie zawsze jeden z końców rys na ogół ma miejsce w strefie styku płyty stropowej ze ścianą szczelinową.

Jedynie pole stropowe przylegające do dwóch wzajemnie prostopadłych odcinków ściany szczelinowej ma nieco odmienny kierunek zarysowania. Pole stropowe przylegające do prostopadłych (narożnych) odcinków ściany szczelinowej ma zarysowania prawie prostopadłe do dwusiecznej kąta jaki tworzą łączące się odcinki ściany szczelinowej. Czyli narożne pole stopu występujące przy narożu ściany szczelinowej ma zarysowanie przebiegające pod kątem około $45^{\circ}$ do zbiegających się odcinków ścian szczelinowych.

Zarysowania nie dotyczą $\mathrm{w}$ równym stopniu wszystkich zewnętrznych pasm stropowych ani pól stropowych z nich wydzielonych. Odległości między rysami są rzędu $0,5 \mathrm{~m}$. Szerokości rys przekraczających 0,2 mm nie zmierzono. Rozwarcia 
rys zawierają się w granicach od $0,05 \mathrm{~mm}$ do $0,10 \mathrm{~mm}$. Występujące przesączanie wód pochodzenia opadowego świadczy o przelotowym charakterze rys. Obraz zarysowań stropu nad poziomem -2 pod względem umiejscowienia rys, ich kierunków, intensywności i szerokości praktycznie nie odbiega od zaobserwowanego nad kondygnacją -1 .

Kierunek powstałych rys wskazuje wyraźnie na powstrzymywanie odkształceń przez istniejące zewnętrzne, obwodowe więzy. Stanowią one tzw. opory liniowe. Płyta stropu w wyniku zachodzących w nim procesów, takich jak wiązanie, twardnienie, skurcz dążyła do swobodnego odkształcenia. Temu odkształceniu przeciwdziałała sztywna w swojej płaszczyźnie ściana szczelinowa do której płyty stropowe były dobetonowywane. Rysy przebiegają prostopadle do przebiegu ściany szczelinowej, która zaoporowała swobodne odkształcenia związane ze skurczem płyty stropowej czy też obniżeniem jej temperatury. Sztywność więzów jest znaczna i wynika nie tylko ze zwykłej przyczepności betonów układanych w różnym czasie. Zbrojenie stropu zostało zakotwione za zbrojenie pionowe ściany szczelinowej. Etapowanie betonowania z użyciem przerw roboczych złagodziło skutki skurczu, ale jak widać całkowicie ich nie wyeliminowało. Tak więc więzy zewnętrzne przyczyniły się do generowania naprężeń rozciągających rozłożonych na pełnej grubości płyty stropowej. Powstrzymywanie odkształceń jest bardzo dobrze widoczne w polach narożnych. Więzy występujące wzdłuż prostopadłych, dwóch kierunków spowodowały powstaniem ukośnych zarysowań, praktycznie prostopadłych do dwusiecznej kąta zbiegających się odcinków ściany szczelinowej.

Zastosowana konstrukcja i przekroje zbrojenia pozwoliły na rozproszenie i ograniczenie szerokości rys od odkształceń wymuszonych. Jeśli szerokości rys nie przekraczają $0,2 \mathrm{~mm}$ to dla klasy ekspozycji XD1 są właściwie normowo dopuszczalne. Dla stropu poziomu -1 przyjęto jednak rozwiązanie natychmiastowego uszczelnienia rys przez wykonanie standardowej iniekcji. W tym celu zastosowano elastyczną żywicę na bazie poliuretanowej.

Zarysowanie uznaje się za inherentną cechę żelbetu. Nie oznacza to jednak zupełnego braku możliwości jego kontrolowania tak w sytuacji początkowej jak i eksploatacyjnej. W przypadkach elementu niemasywnego, a więc takiego jak opisywany może dochodzić do przekroczenia przez naprężenia wymuszone wytrzymałości betonu na rozciąganie. Naprężenia te są generowane parą sprężonych przyczyn. Pierwsza to swobodne odkształcenie, do którego dąży element w wyniku procesów, takich jak wiązanie, twardnienie, skurcz. Druga przyczyną jest opór temu odkształceniu stawiany przez więzy zewnętrzne i nieuniknione wewnętrzne (zbrojenie). Minimalizowanie tego typu naprężeń wymaga zwrócenia uwagi na:

- wielkość i położenie działek roboczych,

- długości łączenia betonu nowego ze starym o już zaawansowanych odkształceniach skurczowych,

- zastosowanie cementu o odpowiednich właściwościach,

- zabiegi pielęgnacyjne,

- temperaturę betonowania.

W prostych przypadkach w celu kontrolowania szerokości zarysowania od odkształceń wymuszonych wyznacza się tzw. minimalny przekrój zbrojenia.

Na podstawie prezentowanego przykładu zarysowania stropów widać, że oddziaływania wymuszone mogą mieć znaczenie i to nie tylko przypadkach konstrukcji określanych mianem masywnych. Minimalizowanie krępowania odkształceń od skurczu i obniżenia temperatury zewnętrznej nabiera szczególnego znaczenia wówczas gdy dodatkową funkcją betonu staje się zapewnienie przegrodzie szczelności. 